AN INTRODUCTION TO MODERN SOCIAL AND POLITICAL THOUGHT 


\section{AN INTRODUCTION TO MODERN SOCIAL AND POLITICAL THOUGHT}

ANDREW GAMBLE 


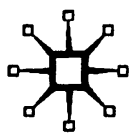

(c) Andrew Gamble 1981

All rights reserved. No reproduction, copy or transmission of this publication may be made without written permission.

No paragraph of this publication may be reproduced, copied or transmitted save with written permission or in accordance with the provisions of the Copyright, Designs and Patents Act 1988, or under the terms of any licence permitting limited copying issued by the Copyright Licensing Agency, 90 Tottenham Court Road, London WIP 9HE.

Any person who does any unauthorised act in relation to this publication may be liable to criminal prosecution and civil claims for damages.

First published 1981 by MACMILLAN PRESS LTD

Houndmills, Basingstoke, Hampshire RG21 6XS

and London

Companies and representatives

throughout the world

ISBN 978-0-333-27029-5

ISBN 978-1-349-16615-2 (eBook)

DOI 10.1007/978-1-349-16615-2

A catalogue record for this book is available from the British Library. 


\section{Contents}

Preface vii

1 The world and the West 1

1 The meaning of the West and the Western tradition 1

2 The coming of world history 5

3 Western social and political thought 8

4 The Western ideology 12

5 Conclusion 16

2 The state and civil society 22

1 The idea of revolution 22

2 The bourgeois revolution 26

3 The Industrial Revolution 31

4 The origins of capitalism 34

5 The state of nature 41

6 Political economy 45

7 The idea of the state 47

8 Sovereignty 49

9 State and civil society 54

10 The new technology 57

11 The new cosmology 58

12 The new philosophy 60

13 Science and the intellectuals 63

3 Liberalism $\quad 66$

1 The political revolutions $\quad 66$

2 The constitutional state $\quad 75$

3 The theory of popular sovereignty $\quad 87$

4 The state as an ethical idea 94

5 Conclusion $\quad 98$

4 Socialism 100

1 The unfinished revolution 100

2 The reaction to laissez-faire 104

3 Rationalism 106

4 Libertarianism 109

5 The origins of Marxism 110 
6 The production of commodities

7 Accumulation

5 Politics and industrial society $I$ :

The national question

1 Introduction 130

2 Nationalism 132

3 The anti-Enlightenment 137

4 Gemeinschaft 146

6 Politics and industrial society II:

The social question

A NATIONAL LIBERALISM

1 The rise of modern industry 151

2 Order and liberty 154

3 Democracy 160

4 Stratification and elites $\quad 168$

B SOCIAL DEMOCRACY

5 The new liberals 173

6 Anomie 176

7 The anarchy and waste of 178 capitalist production $\quad 178$

8 Equality 181

7 Politics and industrial society III:

The spectre of revolution $\quad 186$

1 The Russian Revolution 186

2 Engels and the Second International 188

3 Leninism 197

4 Western Marxism 209

5 Conclusion 215

8 Conclusion 218

Guide to further reading 232

Biographies $\quad 238$

Glossary 254

Index $\quad 262$ 


\section{Preface}

This book is intended as an introduction to Western social and political thought in the modern period, and particularly since the French Revolution. The material that could be included in such a survey is vast, the need for selection great, and I am conscious that much that is important has had to be omitted, and that it has scarcely been possible to deal adequately with the thinkers and the theories that appear in the text. The aim of the book is to encourage all who read it to read further, both the works of some of the writers discussed in these pages and the ever-multiplying literature about them. I have provided a short bibliography which I hope will be useful for this purpose. Biographical material has mostly been left out of the text and placed in a separate section at the end. I have also included a short glossary of some of the more important terms and concepts used in the book, not in an attempt to provide final definitions but for reference.

I do not think it possible to stand outside the Western tradition and pronounce upon its character and its value from the standpoint of eternity. I have not tried to do so. I have tried to be objective and accurate in my exposition of different theories, but the evaluation of them and the selection of what is important is naturally shaped by the overall approach I have adopted.

I have enjoyed writing this book and hope it will be rewarding to read. Many people, teachers, colleagues, and students of mine have contributed to it, most of them unwittingly. I give thanks to them all, but especially to Chris and Tom and Corinna for not complaining too much or too loudly. 